\title{
Modelling of chromite and magnesiochromite solubility in silicate melts at high temperatures
}

\author{
NAIL R. ZAGRTDENOV ${ }^{1}$, MICHAEL J. TOPLIS ${ }^{2}$, DR. \\ ANASTASSIA Y. BORISOVA ${ }^{3}$ AND JÉRÉMY GUIGNARD ${ }^{4}$ \\ ${ }^{1}$ CanmetMINING \\ ${ }^{2}$ Institut de Recherche en Astrophysique et Planétologie \\ ${ }^{3}$ Géosciences Environnement Toulouse \\ ${ }^{4}$ Observatoire Midi Pyrénées, CNRS, IRAP \\ Presenting Author: nailzagrtdenov@gmail.com
}

Chromium is a chemical element of importance in many industrial applications, typically extracted from the mineral chromite. In addition, chromite is used as a petrogenetic indicator of physico-chemical conditions of magmatic processes. Understanding the conditions of chromite formation is thus of interest from both a fundamental and an applied point of view. In this work, an integrated experimental and numerical approach has been performed to predict the solubility of chromite in silicate melts, taking into account parameters such as temperature, oxygen fugacity, and melt composition.

For the experimental part of the work, tests on chromite and chromium oxide equilibration with basalt and haplobasalt melts at high temperature $\left(1440{ }^{\circ} \mathrm{C}\right)$ were performed at 1 bar. The oxygen fugacity of the atmosphere was controlled in each experiment by $\mathrm{CO}-\mathrm{CO}_{2}$ gas mixtures. For the numerical part of the work, our data and that from the literature $[1,2,3]$ were used to derive a thermodynamically based model, including the concept of optical basicity as a proxy for activity coefficient ratios in the silicate melt.

The model describes chromite and magnesiochromite solubility as a function of silicate melt composition, temperature and oxygen fugacity and it may be applied to a wide variety of chromite-bearing systems. The model has been applied to the situation of assimilation of magnesiochromite-bearing serpentinite lithosphere by mafic melts. It is predicted that the $\mathrm{Cr}$ content of the melts increases significantly, triggering massive chromite crystallization. Hybridization, cooling, oxidation and magma degassing are all favorable for this process.

1. Poustovetov A.A. \& Roeder P.L. (2000). The distribution of $\mathrm{Cr}$ between basaltic melt and chromian spinel as an oxygen geobarometer. Canadian Mineralogist. Vol. 39, pp. 309-317.

2. Roeder, P. L. \& Reynolds, I. (1991). Crystallization of chromite and chromium solubility in basaltic melts. Journal of Petrology 32, 909-934.

3. Nikolaev, G.S., Ariskin, A.A. \& Barmina, G.S. (2018). SPINMELT-2.0: Simulation of spinel-melt equilibrium in basaltic systems under pressures up to 15 kbar: I. model formulation, calibration, and tests. Geochemistry International. 56, 24-45. 